\title{
Chapter 17 \\ Development of an Information Package of Radiation Risk in Beef After the Fukushima Daiichi Nuclear Power Plant Accident
}

\author{
Hiromi Hosono, Yuko Kumagai, and Tsutomu Sekizaki
}

\begin{abstract}
This study aimed to improve public knowledge on radiation risk and its management system by providing information for the consumers in order to assist in food purchase decision making. To develop the necessary information, we administered web-based questionnaires twice and conducted two rounds of focus group interviews (FGIs) involving five groups between each questionnaire. Attitude toward food from suffered areas, trust in the risk management sector, and change in the knowledge level with and without providing the information were examined in each questionnaire. FGIs were conducted to identify any insufficient or confusing point in the provided information on radiation risk. As a result, although the risk of radiocesium was not regarded as high compared with other risks in beef, the willingness to pay (WTP) for food from affected areas was lower even if the contamination was checked to be below the regulation level. Public knowledge on current radiocesium contamination in food, risk control measures such as the regulation level and inspection, and health effects of low-dose radiation exposure was limited. The developed information package is available on the website of the Research Center for Food Safety belonging to the University of Tokyo.
\end{abstract}

Keywords Attitude $\bullet$ Information $\bullet$ Knowledge $\bullet$ Risk perception

\footnotetext{
H. Hosono ( $ه)$

Institute for Sustainable Agro-Ecosystem Services, Graduate School of Agricultural and Life Sciences, the University of Tokyo, 1-1-1 Midori-cho, Nishitokyo-shi, Tokyo, Japan e-mail: hiromix@isas.a.u-tokyo.ac.jp

Y. Kumagai • T. Sekizaki

Graduate School of Agricultural and Life Sciences, The University of Tokyo,

1-1-1 Yayoi Bunkyo-ku, Tokyo, Japan
} 


\subsection{Introduction}

On March 11, 2011, the greatest earthquake ever recorded hit Japan. Even more devastating than the earthquake itself was the resulting tsunami and the subsequent accident at Tokyo Electric Power Company's Fukushima Daiichi nuclear power plant. Soon after the explosion at the power plant, the health risks of radioactive substances were of central concern. In terms of food safety, levels of radioiodine and radiocesium that exceeded the provisional regulation levels were detected on March 19, and abnormal levels of these radioactive substances have continuously been detected thereafter, particularly from the area surrounding the power plant. Radioactive contamination caused by the accident was detected at the 1st stage in water, vegetables, fruits, and milk and then in tea leaves in May, beef in July, and rice in September. Thus, public anxiety regarding radiation risk is widespread and has affected the food market, particularly in the Kanto and Tohoku regions, despite the implementation of measures to ensure that foods contaminated above the regulation level were not supplied for human consumption.

On March 17, 2011, the Japanese Ministry of Health, Labor, and Welfare (MHLW) adopted a provisional regulation level of radioactive substances in food to control radiation exposure from foods; this was set at $<5 \mathrm{mSv} / \mathrm{year}$. Under this provisional regulation, the upper limit of radiocesium contamination in drinking water and dairy products was set at $200 \mathrm{~Bq} / \mathrm{kg}$, and the upper limit for other foods such as meat, vegetables, and grains was set at $500 \mathrm{~Bq} / \mathrm{kg}$ (Table 17.1). After risk assessments were made by examining the related literature and consideration was given to public concern, the regulation level was revised upward in April 2012. Under the new standard that considers the maximum permissible dose to be $1 \mathrm{mSv} /$ year for foods, the upper limit of radiocesium in general food was set at $100 \mathrm{~Bq} / \mathrm{kg}$ (50 Bq/kg for milk).

Along with setting the maximum permissible dose of radioactive nuclide contamination in food, public inspections have been intensively conducted around the affected area. Up to the end of March, a total of 136,975 food samples were inspected, and 1,204 of these were found to have radioactive nuclide levels higher than the regulation levels (inspection results are available at the Ministry of

Table 17.1 Provisional regulation levels and the new standard for radioactive nuclides in foods

\begin{tabular}{lclllr}
\hline \multicolumn{2}{l}{ Provisional regulation level } & & \multicolumn{3}{l}{ New standard } \\
\hline \multicolumn{2}{l}{ Radioiodine in food } & & Radiocesium in food & & \multicolumn{2}{l}{ Radiocesium in food } \\
\hline Category & Limit & & Limit & & Limit \\
\hline Drinking water & $(\mathrm{Bq} / \mathrm{kg})$ & Category & $(\mathrm{Bq} / \mathrm{kg})$ & Category & $(\mathrm{Bq} / \mathrm{kg})$ \\
Milk, dairy products & 300 & Drinking water & 200 & Drinking water & 10 \\
Vegetables & 2,000 & Milk, dairy products & 200 & Milk & 50 \\
& & & 500 & General foods & 100 \\
\end{tabular}

Note: Ministry of Health, Labour and Welfare 
Agriculture, Forestry and Fisheries website). Once foods with radiocesium/iodine concentrations higher than the regulation level are detected, shipments of such foods from the same area are restricted, and it takes at least 1 month before normal shipping can be resumed.

Information on the inspection results and shipment restriction areas is available on the MHLW website, which has been updated daily since March 2011. Other information related to radiation risk such as the type of radiation, annual exposure dose under usual conditions, internal and external exposures, and epidemiological findings related to radiation exposure as well as risk control measures taken in Japan after the accident is also provided on the websites of government ministries and agencies. Public forums to discuss radiation risks have been held in each locality.

Many TV programs and newspapers provided commentaries on the radiation risk, measures taken, and current situation regarding radiation contamination of foods as well as efforts to recover from the damage. Other internet-based tools such as social networks and blogs were used by consumers to gather information on radiation risks. Nevertheless, the information gathered from all these sources was sometimes inconsistent, and there have been numerous conflicts of opinions, even among specialists. Given the flood of information, it was difficult for people to judge the radiation risk by consuming food from the affected areas. In this context, many people avoided purchasing food from the affected areas even if these areas had been inspected. Consumer surveys administered after the explosion at the Fukushima Daiichi nuclear power plant revealed that radioactive contamination of food was of major concern and was regarded as the highest risk associated with food consumption (Food Safety Commission 2011; Kito 2012; Hosono and Nakashima 2012; Hosono et al. 2012a).

This study aimed to improve public knowledge on radiation risk caused by the accident and its management in order to assist with food purchasing decisions by providing information.

\subsection{Radioactive Contamination of Beef}

As noted above, no radioactive contamination of beef above the regulation levels was detected until the beginning of July. On July 8 and 9, 11 heads of beef cattle shipped to Tokyo from Minamisoma City in Fukushima Prefecture were found to contain 1,530-3,200 Bq/kg of radiocesium. Thereafter, their feed, water, and environment were intensively investigated. On July 14, rice straw on the beef cattle farm was found to be contaminated with high doses of radiocesium. On July 19, shipments of beef cattle from Fukushima Prefecture were restricted. Thereafter, shipments of cattle from Miyagi, Iwate, and Tochigi prefectures were also restricted. The distribution of the contaminated rice straw was traced, and a blanket inspection of cattle farms was implemented. The shipment ban was gradually reduced and was lifted at the end of August because of the application of intensive inspections at 
slaughter houses. If the source of cattle was a farm where feed control was not confirmed, where there was a possibility of feeding contaminated rice straw, or where radiocesium contamination over regulation levels had been previously identified, the cattle were subjected to intensive inspections at the slaughterhouse (the Government of Japan website 2011). Comprehensive examination of farms was also performed even if it was confirmed that contaminated feed was not provided to the cattle. After the accident, a total of 90,661 beef samples produced in eastern Japan were submitted for public inspection of radiation levels before the end of March 2012. These inspections identified 157 samples that exceeded the provisional regulation level for radiocesium $(500 \mathrm{~Bq} / \mathrm{kg})$ and 1,092 samples that exceeded the new standard $(100 \mathrm{~Bq} / \mathrm{kg})$. Although a blanket inspection of beef was not required publicly, this was voluntarily implemented and covered all slaughtered beef from the affected area to ensure food safety.

During our study on the food safety risk posed by beef, we experienced an outbreak of enterohemorrhagic Escherichia coli $\mathrm{O} 111$ and $\mathrm{O} 157$ from raw beef provided by the BBQ franchise in April 2011; this claimed five lives and more than 100 patients were infected. On this occasion, the standards used to assess raw meat at restaurants and/or shops were re-examined and enhanced to prevent further food poisoning outbreaks. The new code took effect on October 1, 2011. Since the BSE crises in September 2001 and December 2003 (during which the 1st cases were detected in Japan and the US, respectively) and the economic downturn and foot-and-mouth disease outbreak in 2010, the beef market in Japan has been experiencing a tough time.

\subsection{Research Outline}

We conducted a series of studies to develop an information package on radiation, associated health risks, and measures taken to control food radiation risk after accidents for improving the knowledge of consumers. To collect the necessary information, we administered two web-based questionnaires and conducted two rounds of focus group interviews (FGIs) involving five groups between the administration of each questionnaire (Fig. 17.1). Prior to the 1st web questionnaire, we prepared ten slides of information to check its effectiveness. FGI participants were then recruited from the respondents to the 1st questionnaire. Those who were able to attend two FGIs and who had an average level of knowledge were selected as FGI participants.

In the 1st FGIs, we asked the participants to identify any points of confusion and to note any additional information that would help increase the understanding of radiation risk and the measures taken to ensure food safety. During the 1-month interval between FGIs, we prepared 45 slides of information considering the opinions collected during the 1st FGIs. The 45 slides of information were prioritized by each group, and their responses were collated during the 2 nd round of FGIs. The information package provided was developed according to the FGI outcomes. 


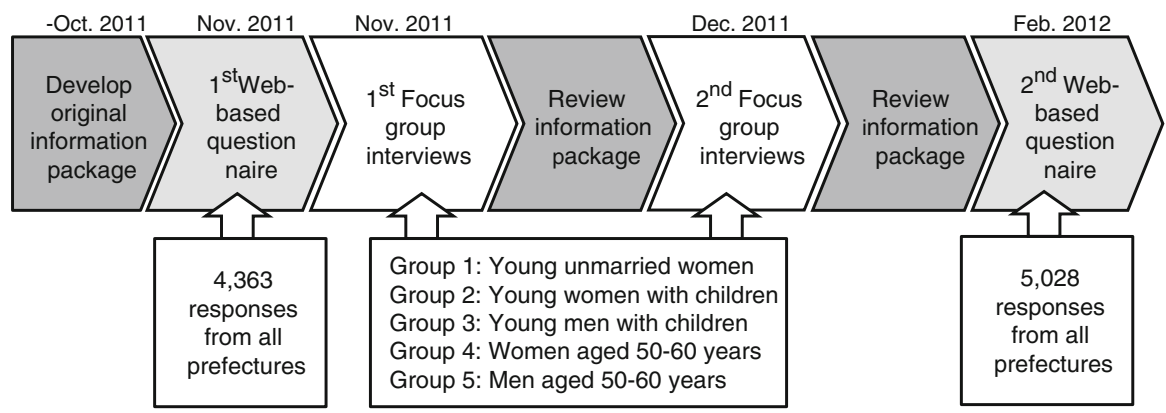

Fig. 17.1 Outline of the study

Table 17.2 Internet-based questionnaire respondents

\begin{tabular}{|c|c|c|c|c|c|}
\hline & & \multicolumn{2}{|l|}{ October 2011} & \multicolumn{2}{|l|}{ March 2012} \\
\hline & & No. of respondents & $\%$ & No. of respondents & $\%$ \\
\hline Total & & 4,363 & 100.0 & 5,028 & 100.0 \\
\hline \multirow[t]{2}{*}{ Sex } & Male & 2,165 & 49.6 & 2,641 & 52.5 \\
\hline & Female & 2,198 & 50.4 & 2,387 & 47.5 \\
\hline \multirow[t]{5}{*}{ Age group } & $20-29$ & 882 & 20.2 & 873 & 17.4 \\
\hline & $30-39$ & 839 & 19.2 & 1,014 & 20.2 \\
\hline & $40-49$ & 864 & 19.8 & 1,078 & 21.4 \\
\hline & $50-59$ & 861 & 19.7 & 1,047 & 20.8 \\
\hline & $60-69$ & 917 & 21.0 & 1,016 & 20.2 \\
\hline \multirow[t]{10}{*}{ Residential area } & Hokkaido & 70 & 1.6 & 95 & 1.9 \\
\hline & Tohoku & 433 & 9.9 & 582 & 11.6 \\
\hline & Kanto & 1,462 & 33.5 & 1,255 & 25.0 \\
\hline & Hokuriku & 281 & 6.4 & 382 & 7.6 \\
\hline & Chubu & 347 & 8.0 & 516 & 10.3 \\
\hline & Kinki & 500 & 11.5 & 624 & 12.4 \\
\hline & Chugoku & 367 & 8.4 & 479 & 9.5 \\
\hline & Shikoku & 292 & 6.7 & 383 & 7.6 \\
\hline & Kyushu & 526 & 12.1 & 629 & 12.5 \\
\hline & Okinawa & 85 & 1.9 & 83 & 1.7 \\
\hline
\end{tabular}

Two internet-based questionnaires monitored by Nikkei Research Inc. were offered in October 2011 and March 2012 to respondents in all the prefectures in Japan. As shown in Table 17.2, the 1st survey had 4,363 respondents and the 2nd had 5,028 respondents. The survey covered the following subjects: (1) risk perception of seven hazards that may be derived from beef; (2) knowledge about radioactive substances, health risks, and control measures taken in Japan after the accident; (3) trust in radiation risk management implemented by the government and food industry; (4) attitude toward food safety and radiation risk management; and (5) intention to purchase food from the affected area. We provided the prepared information pack during the final phase of both the surveys to check whether it led to any improvement in public knowledge. 


\subsection{Results}

\subsubsection{Risk Perception, Knowledge, and Attitude}

Risk perceptions of the seven beef-derived hazards were rated on a scale from 0 (no risk) to 5 (very high risk). The average risk perception score for each hazard is shown in Fig. 17.2. In the 1st survey, the risk of radioactive contamination was ranked 6th among men and 5th among women. The risk of enterohemorrhagic $E$. coli was ranked the highest by both men and women, followed by the risk of Salmonella spp. infection. Women perceived the risk of bovine spongiform encephalopathy as the 3rd highest, whereas men perceived the risk of Campylobacter spp. infection as the 3rd highest. In the 2nd survey, which was administered 1 year after the Fukushima Daiichi nuclear power plant accident, enterohemorrhagic E. coli infection was also regarded as the highest risk. The perceived risk levels of the three bacterial hazards were lower than those in the 1st survey. However, the perceived risk of bovine spongiform encephalopathy, radioactive contamination, and antibiotic residues was similar. Consequently, the risk of radioactive contamination was ranked 2nd among women and 5th among men in March 2011. Risk perception by women was higher than that by men for all the presented hazards $(p<0.05)$.

Knowledge related to food poisoning, bovine spongiform encephalopathy, and radioactive contamination was classed as subjective or objective in the 1st survey. Subjective knowledge was tested in the following five categories: "I am well informed about health risks and measures to control such risks," "I have some knowledge about health risks and measures to control these," "I know about health

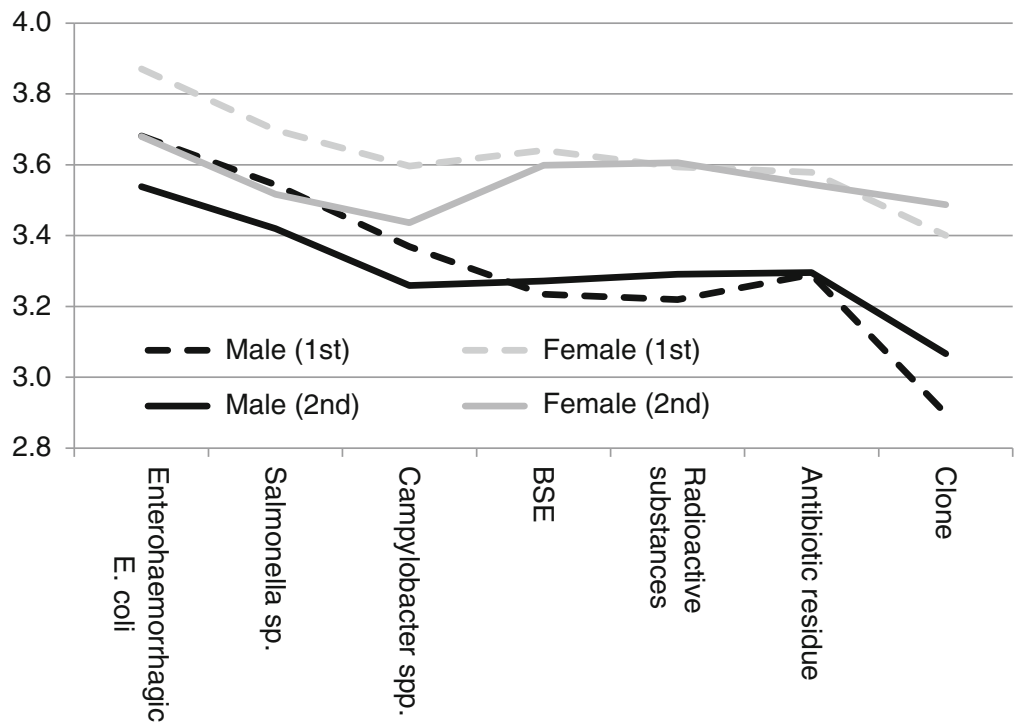

Fig. 17.2 Risk perception of seven hazards in beef. Number indicates the average score on a scale from 0 (no risk) to 5 (very high risk) 
risks," "I do not have detailed knowledge of health risks, but I have heard of them," and "I have never heard of health risks." For each hazard, the 1st row indicates the number of respondents who indicated that they had respective subjective knowledge of the hazard. To evaluate their objective knowledge, five correct or incorrect descriptions of three hazards were included, and the respondent had to indicate whether he/she thought that these descriptions were correct, incorrect, or whether he/she did not know. The proportion of correct responses is shown in relation to subjective knowledge responses in Table 17.3.

Knowledge related to food poisoning, such as the implementation of stricter raw beef hygiene restrictions and the fact that food poisoning cannot always be prevented even in frozen or heat-treated foods, was comparatively well known. The 1st case of bovine spongiform encephalopathy in Japan was detected in September 2001, and this disrupted the beef market. One month later, blanket inspections were introduced to stabilize the market. Even among respondents who thought that they knew about the disease, $30 \%$ did not realize that bovine spongiform encephalopathy had occurred in Japan. Less than half people realized that the causative agent of bovine spongiform encephalopathy is concentrated in the brain or neurological system and is rarely found in beef. This indicates the possibility that the information provided during and after the bovine spongiform encephalopathy outbreak focused more on the introduction of blanket testing and less on scientific knowledge and effective control measures for preventing the disease ${ }^{1}$ (Hosono et al. 2012b).

Objective knowledge on radioactive contamination was correlated with subjective knowledge. However, more than $70 \%$ of the respondents did not realize the radiation exposure from food under control, the fact that careful inspection is required before lifting the shipment restriction, and the fact that gene has repair function.

The knowledge section of the 2 nd survey was focused more on radiation risk. Similar to the 1st survey, the questions used to evaluate the knowledge level consisted of correct and incorrect descriptions that the respondents had to rate as "true," "false," or "do not know." The proportion of correct answers to each question is shown in Fig. 17.3. Radioactive cesium control measures, the level of exposure from food, as well as the fact that radiation does not always cause cancer were well known. Although the terms Becquerel and Sievert appeared frequently in the media after the accident, only $38 \%$ of the respondents realized the meaning of these units. Moreover, $<20 \%$ of the respondents realized the probability of health effects caused by radiation, knew about the procedures used to lift shipment restrictions, or knew that the interim regulation level for food was set to $<5 \mathrm{~m} \mathrm{~Sv} / y e a r$. Public understanding of the health effects of exposure to low-dose radiation and knowledge of the current contamination level and food control measures were shown to be limited.

Approximately $70 \%$ of the respondents thought that food should not be sold if even the slightest radiocesium was detected, and only $20 \%$ thought that blanket farm inspections were costly in terms of both money and time and were therefore unnecessary (Table 17.4). In contrast, $>40 \%$ of the respondents did not care about

\footnotetext{
${ }^{1}$ Approximately $70 \%$ Japanese do not feel safe to consume beef that had not been subjected to inspection for bovine spongiform encephalopathy and agree to continuous blanket inspections.
} 


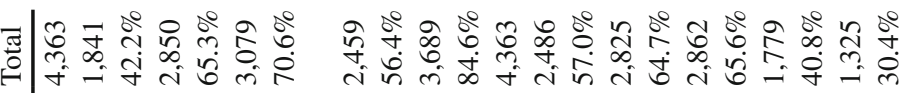
+

离

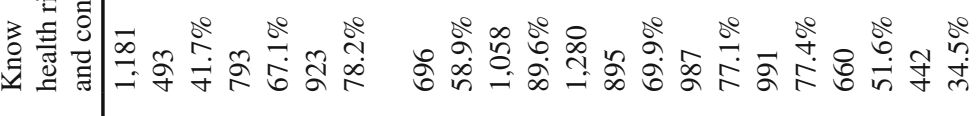

苨

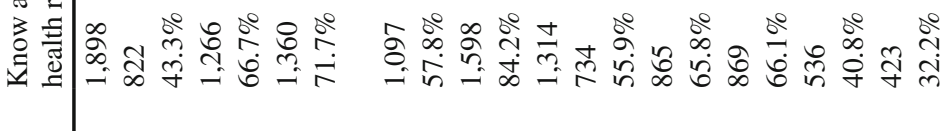

$\stackrel{\varpi}{\varrho}$

$\bar{\Xi} \overline{0}$

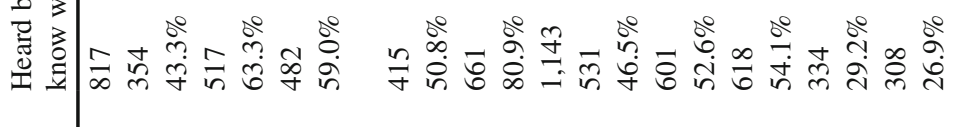

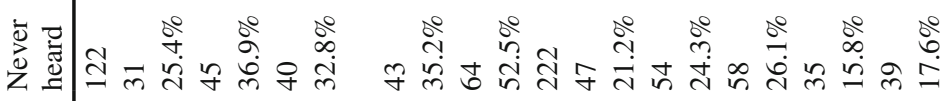

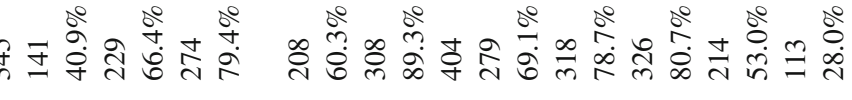

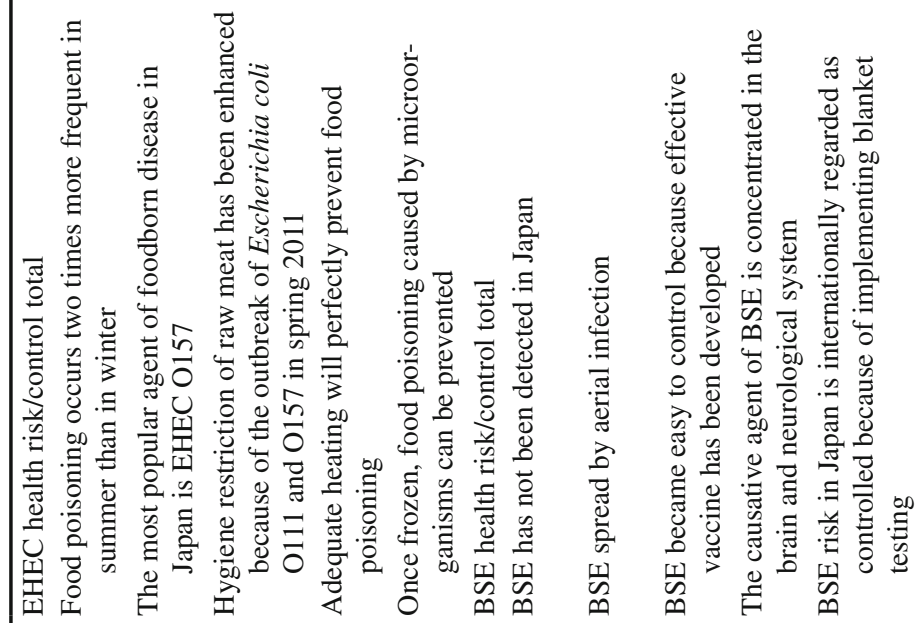

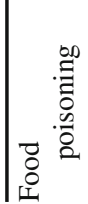


17 Development of an Information Package of Radiation Risk...

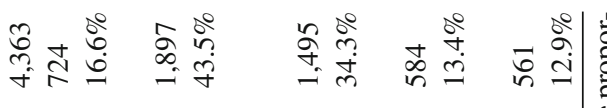

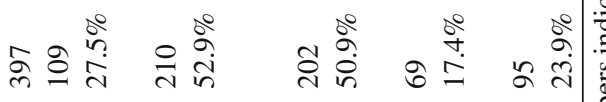

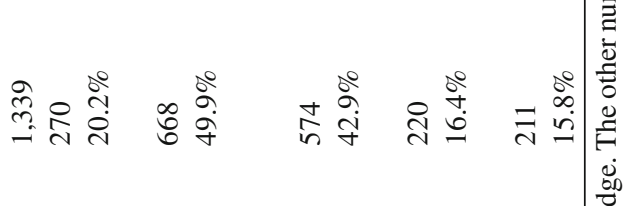

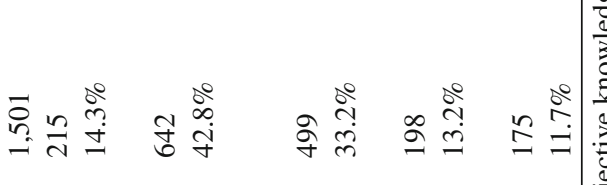

অㅇำ

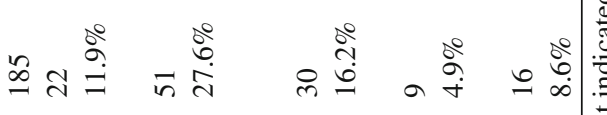

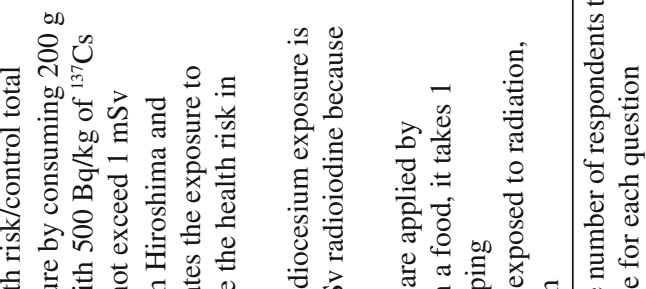

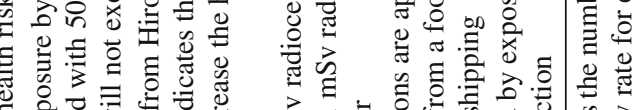

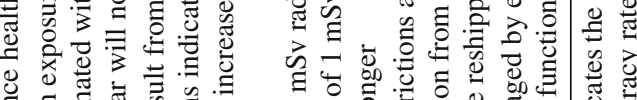

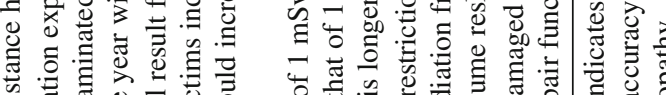

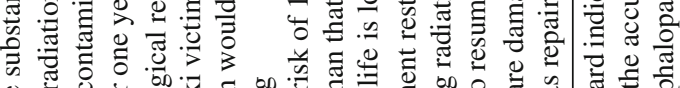

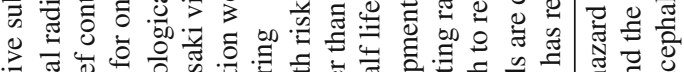




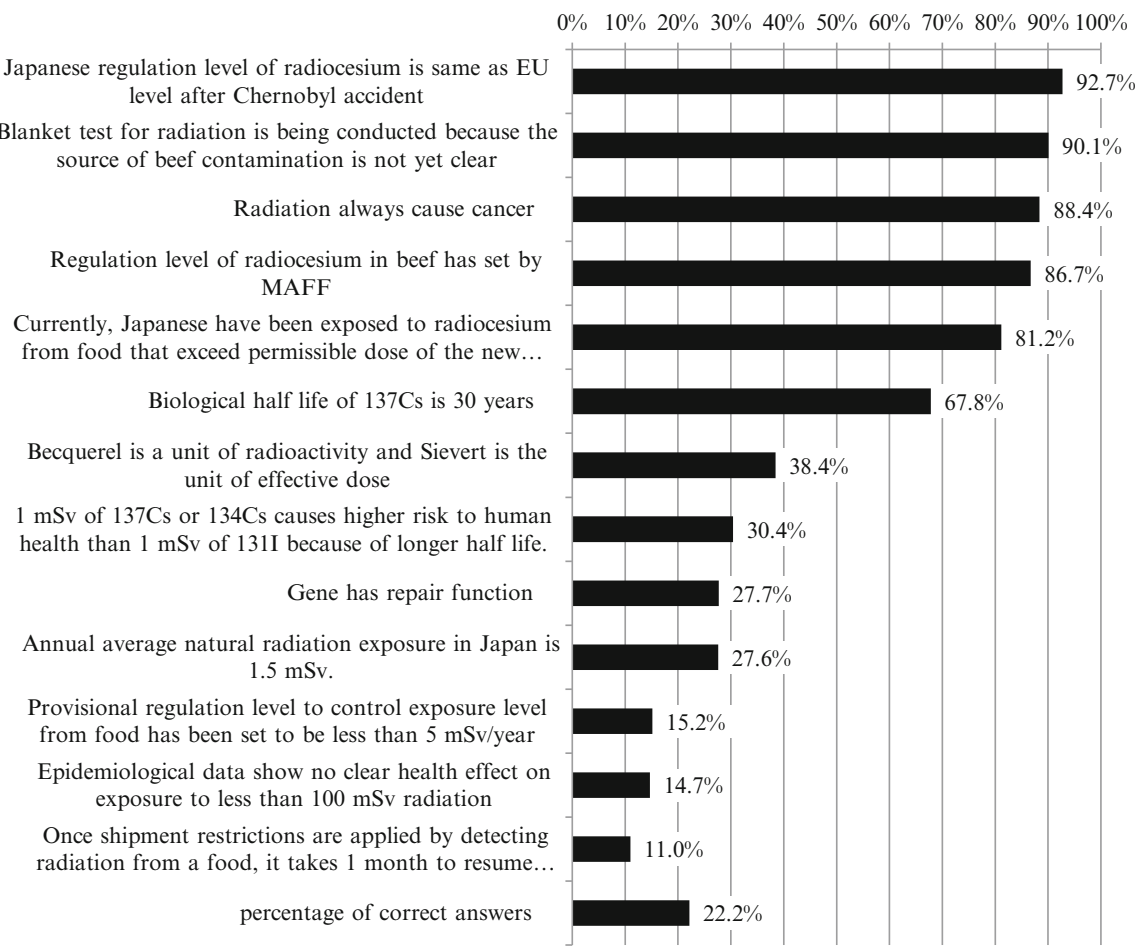

Fig. 17.3 Objective knowledge of the 2nd survey respondents. The numbers indicate the proportion of correct answers for each description

Table 17.4 Attitude on radiation control in food

\begin{tabular}{|c|c|c|c|c|}
\hline & \multicolumn{2}{|l|}{ 1st survey } & \multicolumn{2}{|l|}{ 2nd survey } \\
\hline & Agree (\%) & $\begin{array}{l}\text { Relatively } \\
\text { agree }(\%)\end{array}$ & Agree (\%) & $\begin{array}{l}\text { Relatively } \\
\text { agree }(\%)\end{array}$ \\
\hline $\begin{array}{l}\text { Food should not be sold if a slightest } \\
\text { radiocesium is detected }\end{array}$ & 30.0 & 27.0 & 27.7 & 30.7 \\
\hline $\begin{array}{l}\text { Not necessary to inspect all farms because } \\
\text { it is costly in terms of time and money }\end{array}$ & 6.9 & 15.8 & 4.6 & 16.5 \\
\hline $\begin{array}{l}\text { I do not care because food containing } \\
\text { radiation above regulation level would } \\
\text { not be sold }\end{array}$ & 16.4 & 30.3 & 14.4 & 32.7 \\
\hline $\begin{array}{l}\text { I try not to care because the risk of } \\
\text { radioactivity from food is not so high }\end{array}$ & 13.3 & 31.3 & 11.5 & 31.6 \\
\hline
\end{tabular}

the radiation risk because food containing levels above the regulation level would not be sold or because the risk of radioactive contamination from food is not high. However, the trustworthiness of central and local government agencies in terms of their ability to control radioactive contamination of food was not high (Fig. 17.4). The trustworthiness of food manufacturers and retailers was comparatively higher; however, only $30 \%$ of the respondents trusted their ability to implement radioactive 


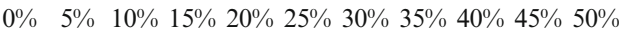

I think the government provide enough information to judge the radiation risk in food

I trust on central government of radioactivity control in food

I trust on local government of radioactivity control in food

I trust on manufacturers of radioactivity control in food

I trust on food retailers of radioactivity control in food

The stricter, the better about the radioactivity regulation level

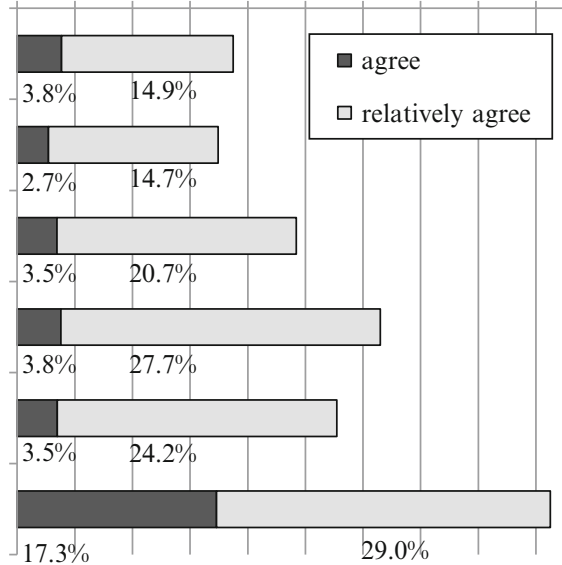

Fig. 17.4 Trustworthiness of risk management agents and risk control (2nd survey)

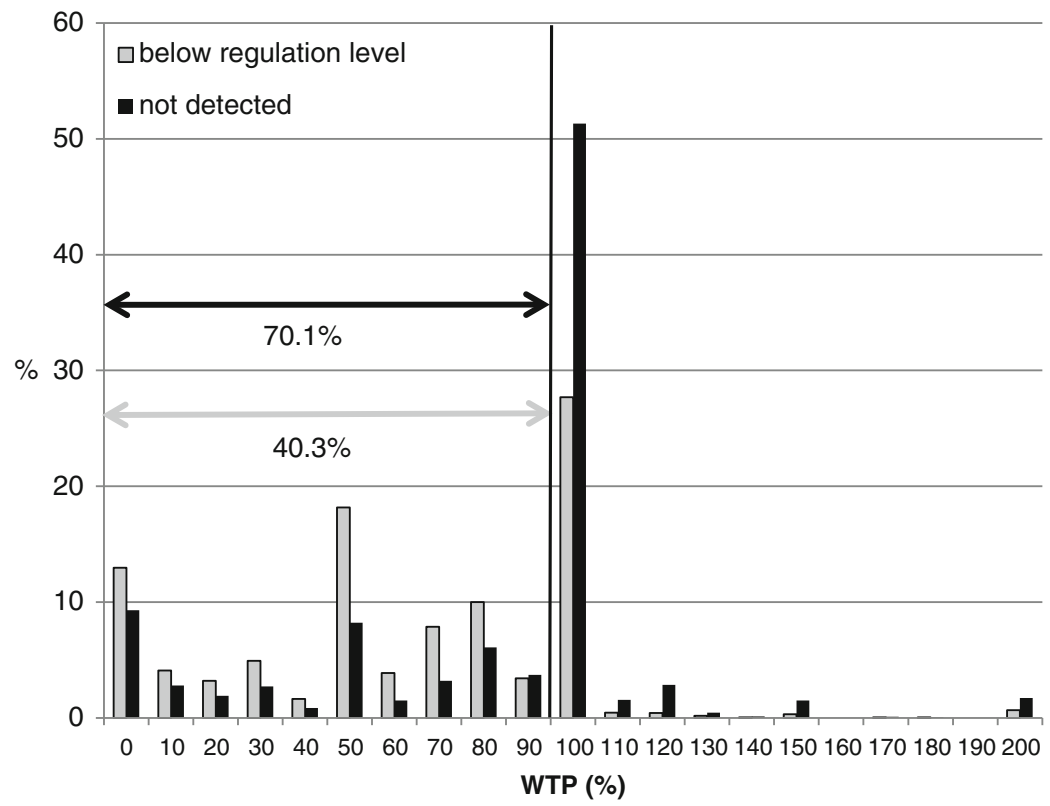

Fig. 17.5 Willingness to pay (WTP) for the food from affected area (1st survey)

contamination control. To ensure food safety, $17.3 \%$ of the respondents $(46.3 \%$ of those who indicated relative agreement) considered "the stricter, the better" about the radioactivity regulation level. Approximately $20 \%$ of the respondents considered the provided information to be insufficient to judge the radiation risk in food.

The willingness to pay (WTP) for the food from affected areas if the radioactive contamination level was inspected and proven to be lower than the regulation level or not detected was also investigated (Figs. 17.5 and 17.6). Answers ranged from $0 \%$ to 


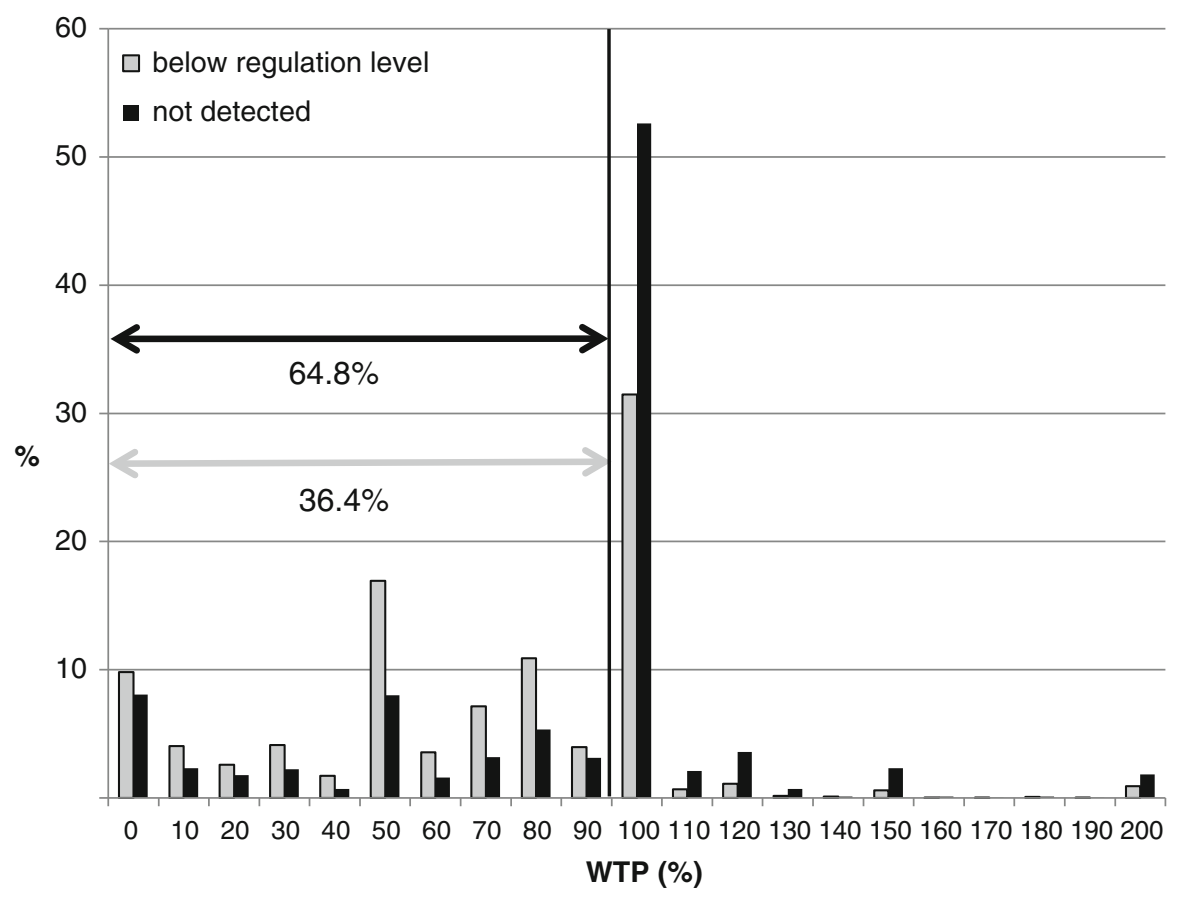

Fig. 17.6 Willingness to pay (WTP) for the food from affected areas (2nd survey)

$200 \%$ assuming that the price of food derived from an unaffected area was $100 \%$. The average relative WTP if radioactive contamination was lower than the regulation level and was not detected was $62.1 \%$ and $80.5 \%$, respectively, in the 1 st survey and $67.6 \%$ and $83.8 \%$, respectively, in the 2nd survey. Approximately $70 \%$ (1st survey) and $65 \%$ (2nd survey) of the respondents provided WTP ratings lower than $100 \%$ for food from affected areas even if radioactive contamination was below regulation levels. Even if radioactive substances were not detected, $40.3 \%$ (1st survey) and $36.3 \%$ (2nd survey) of the respondents provided WTP ratings less than 100\%. Approximately $10 \%$ of the respondents did not want to consume food from affected areas ( $0 \%$ WTP). In contrast, $8.4 \%$ (1st survey) and $11.0 \%$ (2nd survey) of the respondents provided WTP ratings over $100 \%$ if radioactive substances were not detected.

\subsubsection{Effectiveness of the Information Package}

To determine whether the prepared information improved the understanding of radiation risk and control measures, we provided the respondents with four types of information: narration and captions with and without information on beef cattle raising processes (slide 10) in the 1 st survey. It took $2-3$ min to view the slide. The contents of the prepared slide included the following information: (1) internal and external radiation exposure, (2) natural radiation exposure levels, (3) regional 


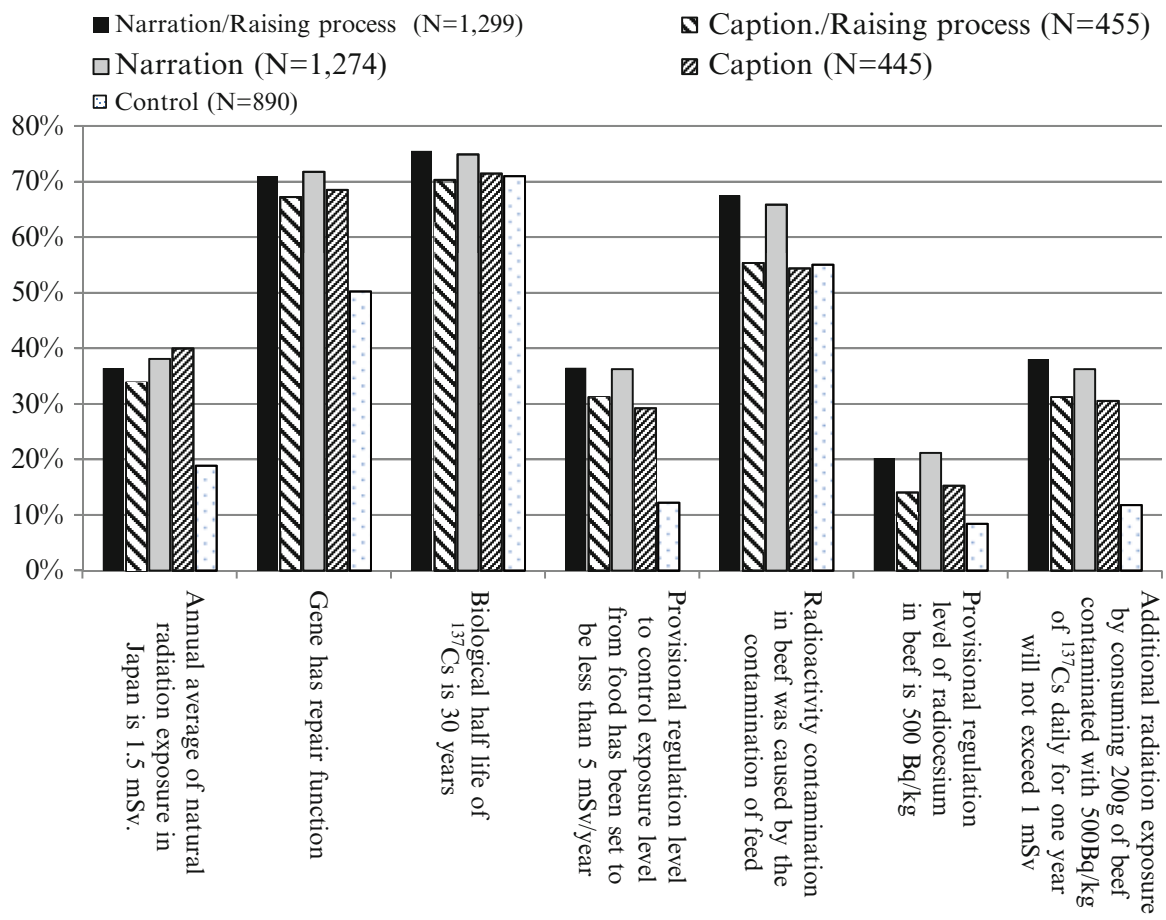

Fig. 17.7 Information pattern and proportion of correct answers (1st survey)

differences in natural radiation exposure levels, (4) effects of exposure on cells/ genes and the repair function of genes, (5) physical half life and biological half life, (6) the provisional regulation level in food, (7) the concept behind the setting of provisional regulation levels, (8) radioactivity inspections of food, (9) reasons for radiocesium contamination in beef and exposure levels after consuming $200 \mathrm{~g}$ of $500 \mathrm{~Bq} / \mathrm{kg}$ radiocesium-contaminated beef daily for 1 year, and (10) the process used to raise beef cattle.

One-fifth of the respondents formed a control group and were not provided with any of the information outlined above. We included seven correct or incorrect descriptions in the questionnaire, and the respondents were asked to indicate if these were "true," "false," or "did not know" after the information was provided. Figure 17.7 shows the proportion of correct answers, which indicates the effectiveness of the information provided to improve understanding. The proportion of correct answers among the control group was $32.5 \%$, whereas that among respondents provided information with and without narration was $49.2 \%$ and $43.8 \%$, respectively. Information with narration was better at improving understanding than that with figure captions.

Because narration was shown to improve understanding about radiation risk in the 1st survey, we prepared two information packages for the 2 nd survey. These packages took 5 or $10 \mathrm{~min}$ to view, and the respondents chose one of them by themselves. If they began viewing the information and thought it was too long or not 


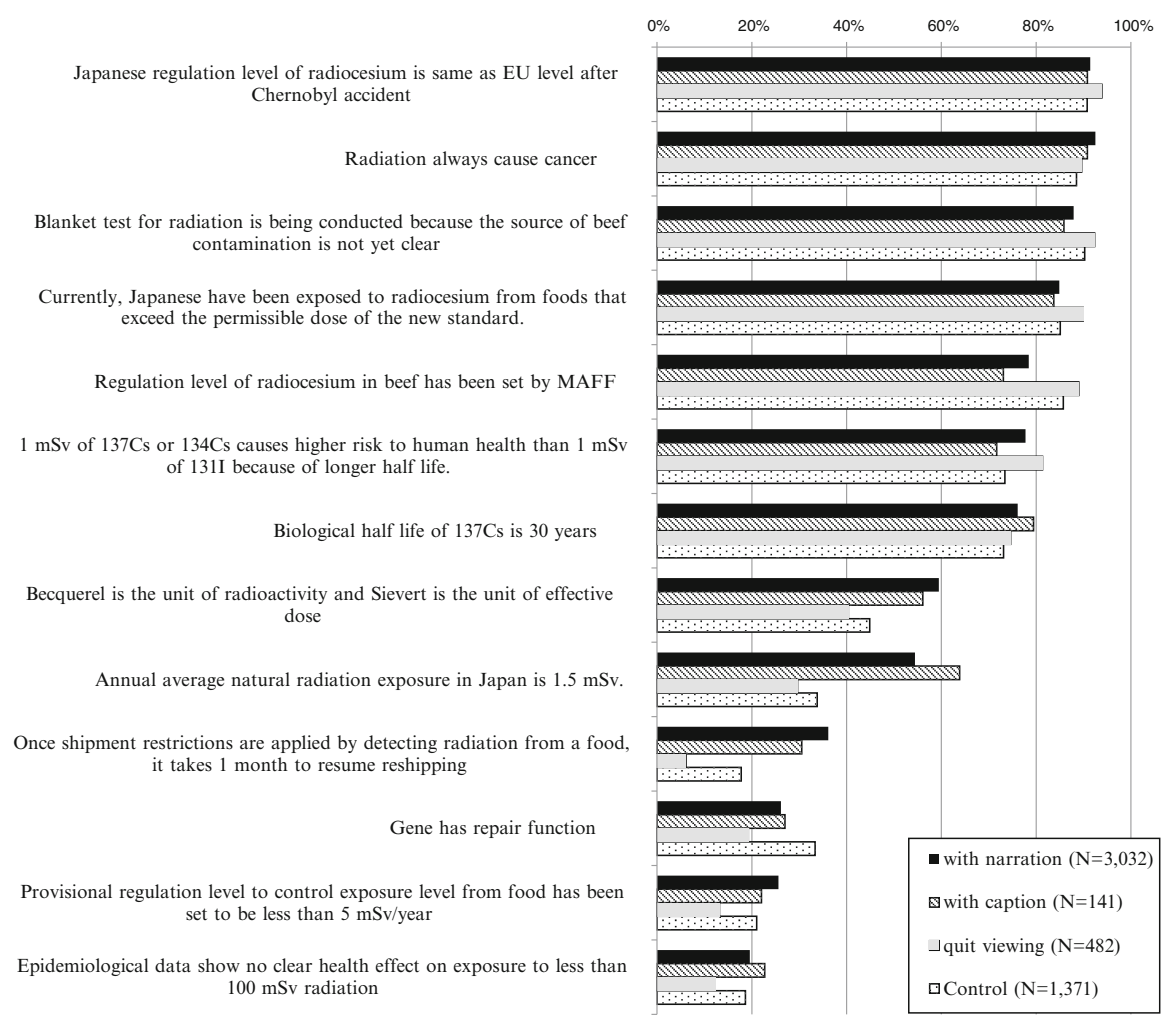

Fig. 17.8 Information pattern and proportion of correct answers (2nd survey)

interesting, they could stop watching it. For those who could not hear the narration when they viewed the slides on the website, we prepared 5- and 10-min versions with captions. Only 353 respondents selected the 10-min version, and 327 of these stopped viewing the slides in the middle of the show. As shown in Fig. 17.8, the information provided in the 2nd survey improved understanding of the meaning of Becquerel and Sievert, annual natural radiation exposure levels, and the process of lifting shipment restrictions. The responders who stopped viewing the information already knew about the topics that were well known among Japanese at the time of the survey. However, the knowledge on control measures, e.g., the regulation level and shipment restriction, as well as the health effects of low-dose exposure was limited among those who quit viewing.

\subsubsection{Results of FGIs}

Two rounds of FGIs were held for $2 \mathrm{~h}$ in November and December 2011; these involved 30 participants in five groups: unmarried women, women with children 
$<12$ years old, men with children $<12$ years old, women aged 50-60 years, and men aged 50-60 years. The topics discussed were the concern for general food safety issues, including radiation exposure from food, as well as any additional information they enquired about related to radiation risk and its management. The results of FGIs are summarized in Table 17.5. Regarding food safety in general, the participants addressed pesticide residues, food additives, genetic engineering, food poisoning (particularly from raw meat), bovine spongiform encephalopathy, dioxin, allergens, radionuclide contamination, and anxiety around animal cloning. Because of a recent repeated mislabeling incident, distrust of processed food was mentioned by both women and men who had young children.

The information required to improve understanding about the radiation risk was similar among the groups. All the groups indicated that they lacked information on the relationship between the exposure level and adverse health effects. Among the younger groups, radiation risk according to age, particularly the adverse health

Table 17.5 Summary of the focus group interviews

\begin{tabular}{|c|c|c|}
\hline Group & Consciousness for food safety & $\begin{array}{l}\text { Comments of necessary information on the } \\
\text { problems caused by radioactive substances } \\
\text { in foods }\end{array}$ \\
\hline $\begin{array}{l}\text { Mothers with } \\
\text { children } \\
<6 \text { years }\end{array}$ & $\begin{array}{l}\text { - Country of origin } \\
\text { - Adverse effect } \\
\text { on children } \\
\text { - Agricultural } \\
\text { chemicals, dioxin } \\
\text { - Price }\end{array}$ & $\begin{array}{l}\text { - Easy-to-understand explanation on } \\
\text { - Examination methods, examination plans } \\
\text { of local governments and the central } \\
\text { government } \\
\text { - Process of establishing the standards of } \\
\text { radioactive substances in foods } \\
\text { - Relationship between Sv and Bq } \\
\text { - Differences of adverse effects between } \\
\text { children and adults } \\
\text { - Interpritation of "half life", "probabilistic } \\
\text { effect", and "determistic effect" } \\
\text { - Cuntermeasures for radioactive substances } \\
\text { at foreign areas indicating higher level of } \\
\text { radioactivity } \\
\text { - Comparison with other risks } \\
\text { - Management of risk for radioactive } \\
\text { substances in foods }\end{array}$ \\
\hline $\begin{array}{l}\text { Married } \\
\text { women } \\
\text { (from } 50 \\
\text { to } 60 \\
\text { years old) }\end{array}$ & $\begin{array}{l}\text { - Country of origin } \\
\text { - Adverse effect } \\
\text { on children } \\
\text { - Agricultural } \\
\text { chemicals, } \\
\text { dioxin } \\
\text { - Price } \\
\text { - Degree of confidence } \\
\text { for retails, super-market, } \\
\text { restaurants, and others }\end{array}$ & $\begin{array}{l}\text { - Easy-to-understand explanation of } \\
\text { examination methods } \\
\text { - Easy-to-understands explanation of the } \\
\text { process of establishing the standards of } \\
\text { radioactive substances in foods } \\
\text { - Interpritation of "half life" } \\
\text { - Information on what we have to do now } \\
\text { - Countermeasures for radioactive substances } \\
\text { at foreign areas indicating higher level of } \\
\text { radioactivity }\end{array}$ \\
\hline
\end{tabular}


Table 17.5 (continued)

\begin{tabular}{|c|c|c|}
\hline Group & Consciousness for food safety & $\begin{array}{l}\text { Comments of necessary information on the } \\
\text { problems caused by radioactive substances } \\
\text { in foods }\end{array}$ \\
\hline $\begin{array}{l}\text { Un married } \\
\text { women } \\
\text { (from } 20 \\
\text { to } 30 \\
\text { years old) }\end{array}$ & $\begin{array}{l}\text { - Country of origin } \\
\text { - Foodborne diseases } \\
\text { - Agricultural chemicals } \\
\text { - Food additives } \\
\text { - Radioactive substances }\end{array}$ & $\begin{array}{l}\text { - Easy-to-understand explanation of } \\
\text { examination methods, inspection plans of } \\
\text { local government and the central } \\
\text { government } \\
\text { - Easy-to-understand explanation of the } \\
\text { process of establishing the standards of } \\
\text { radioactive substances in foods } \\
\text { - Relationship between Sv and Bq } \\
\text { - Interpritation of "half life" } \\
\text { - Countermeasures for radioactive sub- } \\
\text { stances at foreign areas indicating higher } \\
\text { level of radioactivity }\end{array}$ \\
\hline $\begin{array}{l}\text { Fathers with } \\
\text { children } \\
<6 \text { years }\end{array}$ & $\begin{array}{l}\text { - Country of origin } \\
\text { - Risks for hazards in foods, } \\
\text { for example GMO, BSE, } \\
\text { food additives, environmental } \\
\text { endocrine disruptors, } \\
\text { agricultural chemicals, } \\
\text { radioactive substances } \\
\text { - Food labeling }\end{array}$ & $\begin{array}{l}\text { - Adverse effect on children, } \\
\text { - What type of foods cause adverse health } \\
\text { effect } \\
\text { - How much children can eat } \\
\text { - Comparison with other risks } \\
\text { - Comparison with similar accidents such as } \\
\text { Chernobyl and atomic bomb }\end{array}$ \\
\hline $\begin{array}{l}\text { Married men } \\
\quad \text { (from } 50 \\
\quad \text { to } 60 \\
\quad \text { years old) }\end{array}$ & - Management of food safety & $\begin{array}{l}\text { - Easy-to-understand explanation of the } \\
\text { process of establishing the standards of } \\
\text { radioactive substances in foods } \\
\text { - Comparison with similar accidents } \\
\text { - Epidemiological study for radiation } \\
\text { technologists, pilots, and other occupations } \\
\text { - Relationship between examination data and } \\
\text { adverse effects on human health } \\
\text { - Comparison with other risks } \\
\text { - Countermeasures for radioactive sub- } \\
\text { stances at foreign areas indicating higher } \\
\text { level of radioactivity }\end{array}$ \\
\hline
\end{tabular}

effects on young children, was of primary concern. All the groups wanted to know their radiation exposure level caused by the Fukushima Daiichi nuclear power plant accident compared with that caused by past accidents, high-risk occupations, and residence in high-dose regions.

In addition to the exposure level and health effects, a lack of information on control measures was also indicated. The participants considered that the public was not well informed of the concept of a provisional regulation level, the frequency of inspections of targeted areas, the location of the targeted areas, or the inspection regime used. Although detailed information is available on websites, it may be difficult for consumers to find the information that they would like to know or it may be difficult to understand. Some young participants required simply a declaration that the "food is safe" because it is too difficult to understand the radiation risk. 
Another opinion was expressed about the objective of the information provided. We assumed consumers would be able to judge the risk of radiation from food by gaining an understanding of the radiation risk. Therefore, the information provided consists of scientific facts related to radiation and health risks as well as control measures taken after the Fukushima accident. The objective of the provided information was to improve understanding. However, the expectation of the participants was different. They wanted clearer message such as "food is safe" or "be careful when choosing food."

The information package developed through this study is available on the website of the Research center for Food Safety, the University of Tokyo (http://www. frc.a.u-tokyo.ac.jp/event/radioactive/radioactive.html).

\subsection{Conclusion}

After the explosion at the Fukushima Daiichi nuclear power plant, radioactive substances in food became a major concern of Japanese consumers. Some people avoided purchasing food from affected areas, particularly from Fukushima Prefecture, even if it was intensively inspected. According to opinions obtained in this study, this was because the inspections were not comprehensive. Therefore, consumers are anxious whether the food in front of them is properly controlled or has been inspected and found to be safe. Moreover, knowledge on radionuclides, the meaning and magnitude of Becquerel and Sievert measures, exposure levels, health effects, the concept of a regulation level, and risk control measures was limited. If the relationship between the exposure level, health effects, and regulation levels is not realized, people would not feel safe even if food is controlled and found to be below the regulation level. In this context, it is natural for people to require stricter radioactivity regulations. Choosing food inspected and shown to be free of radiation or food from an unaffected area is one means of feeling secure. Information connecting the current contamination level and its health effects should be provided to the public in an easy-to-understand format. Otherwise, it will be difficult for the public to feel secure, even with a lower regulation level.

Open Access This article is distributed under the terms of the Creative Commons Attribution Noncommercial License which permits any noncommercial use, distribution, and reproduction in any medium, provided the original author(s) and source are credited.

\section{References}

Consumer Affair Agency website. Food and Radiation Q\&A (August 25, 2011). http://www.caa.go.jp/

Food Safety Commission. Consumer survey on food safety concerns. Implemented in August 2011. http://www.fsc.go.jp/monitor/2308moni-kadai-kekka.pdf (in Japanese) 
Hosono H, Nakashima Y (2012) After the Fukushima nuclear power plant accident: how Japanese rate the risk of radioactive substances in beef? In: 15th AAAP proceedings. Bangkok, Thailand

Hosono H, Kumakagi Y, Sekizaki T (2012a) Trust, knowledge, attitude and beef-related risk perception focusing on radioactive substances in Japan. In: 15th AAAP proceedings. Bangkok, Thailand

Hosono H, Yamaguchi M, Shirai J (2012b) Japanese consumer's Evaluation of FMD Vaccinated Meat. In: The ' 12 study conference of the Farm Management Society of Japan (in Japanese) Miyazaki, Japan

Kito Y (2012) How does the lay-public consider the health risk of radioactive substances? An analysis based on an internet-based survey. Agric Econ 78(1):18-29 (in Japanese)

Ministry of Agriculture, Forestry and Fisheries website. The Great East Japan Earthquake (October 23, 2012). http://www.maff.go.jp/e/quake/press_110312-1.html

Ministry of Health, Labour and Welfare website. Information on the Great East Japan Earthquake (October 23, 2012). http://www.mhlw.go.jp/english/topics/2011eq/index. html\#corrected15Aug2012

The Government of Japan website. Government Actions to Ensure the Safety of Beef and Other Food (August 29, 2011). http://www.kantei.go.jp/foreign/kan/topics/201108/measures_ beef.pdf 